\title{
The Promise of Pragmatism: Richard Rorty and Business Ethics
}

\author{
Sareh Pouryousefi \\ Ryerson University \\ R. Edward Freeman \\ University of Virginia
}

Pragmatists believe that philosophical inquiry must engage closely with practice to be useful and that practice serves as a source of social norms. As a growing alternative to the analytic and continental philosophical traditions, pragmatism is well suited for research in business ethics, but its role remains underappreciated. This article focuses on Richard Rorty, a key figure in the pragmatist tradition. We read Rorty as a source of insight about the ethical and political nature of business practice in contemporary global markets, focusing specifically on his views about moral sentiments, agency, and democratic deliberation. Importantly for business ethicists, Rorty's approach sets in stark relief our moral responsibility as useful, practical thinkers in addressing the societal challenges of our time. We use "modern slavery" as an empirical context to highlight the relevance of Rorty's approach to business ethics.

Key Words: Richard Rorty, pragmatism, moral sentiments, agency, democratic deliberation

Accepted for publication in Business Ethics Quarterly in January 2021 
A standard assumption in management and organization studies is that individuals engage in economic interactions voluntarily and legitimately. In reality, this assumption does not hold for a growing population of workers around the world: the International Labour Organization (ILO) characterizes forced labor as the illegitimate use of force and nonvoluntary engagement of labor. This includes threats, or actual physical harm, to workers; confinement and restriction of movement in general or at the workplace; debt bondage, whereby individuals work to pay off loans and are not paid for their services; withholding of wages or excessive wage reductions in violation of preexisting agreements; and retention of passports and identification documents to prevent workers from leaving (International Labour Organization [ILO] 1930, 2005). As a by-product of the global production system, forced labor is often studied under the banner of modern slavery, which is defined as "any situation of exploitation that a person cannot refuse or leave because of threats, violence, coercion, deception, and/or abuse of power" (ILO 2017).

Although modern slavery has received attention as a managerial practice and a governance problem (Caruana et al. 2020; Crane 2013; Bales and Trodd 2013; Gold, Trautrims, and Trodd 2015; LeBaron and Crane 2019), its moral relevance remains relatively understudied by business ethicists. To be sure, the ethics of exploitative labor has been receiving attention in business ethics for some time, for example, in work on sweatshop labor (Arnold and Bowie 2003), business and human rights (Wettstein 2009), and responsible international business (Donaldson 1989). Modern slavery deserves the critical scrutiny of business ethicists because it extends beyond specific issues and violations across most supply chains in global industrial markets, not just in exploitative, poorly regulated labor markets or under autocratic dictatorships but across the United States, Europe, and the Global South (Global Slavery Index [GSI] 2018). The corporate structures, demand markets, and social norms that sustain modern slavery entail distinctive sociopolitical and ethical challenges. Even the vocabulary of modern slavery is noteworthy. Many may associate the term slavery with the 
categorically reprehensible historical institutions of the transatlantic slave trade and chattel slavery. Calling slavery "modern" may thus be seen to diminish the moral egregiousness of an important historical phenomenon. What we need is a considered view that questions, or supports, the adoption of the vocabulary of modern slavery in business practice. Business ethicists are well placed to formulate such a view within an inquiry into the ethical significance and implications of modern slavery.

In light of these tasks, this article presents pragmatism as a useful approach in the business ethics toolbox. Instead of searching for abstract moral principles associated with a transcendental notion of truth, pragmatists can ask, what is business ethics good for; how can business ethicists make a practical difference in contemporary global markets; and how can we inform useful conversations and encourage moral progress in response to pressing global challenges? Given its practice orientation and its focus on social norms, pragmatism is particularly well suited for research in business ethics, but its role remains underappreciated (exceptions include Freeman et al. 2010; Wicks and Freeman 1998; Werhane 1999). The practice and vocabulary of modern slavery, and the prevailing norms that legitimize it, are ripe for critical scrutiny through the lens of pragmatism.

To demonstrate the potential of a pragmatist business ethics, we draw on the work of Richard Rorty, a key figure in the pragmatist tradition. Rorty's earlier writings involve a critical diagnosis of dominant themes in modern philosophy, whereas his later work offers a conception of philosophy that sets out a political role and an ethical responsibility for philosophers in public discourse. Interpreting Rorty's later political writings in relation to his earlier work is a contentious matter among Rorty scholars and critics. In this article, we read Rorty's later writings as an "extended meditation on the lessons from the earlier work" (Brandom 2011, 107). We demonstrate that his project of "confronting ourselves and our practices in ethical and political terms" (Ramberg 
2008, 445), present throughout Rorty's work, can reorient business ethics debates about labor practice in contemporary global markets.

In section 1 of the article, we discuss Rorty's thoroughgoing, historicist critique of epistemology and modern philosophy before considering his positive, conversational approach to philosophy as a tool for a purpose as opposed to an abstract preoccupation with truth, objectivity, knowledge, and reality. Extending from this philosophical stance, in section 2 of the article, we discuss Rorty's political view, which involves a distinctive approach to social interaction and deliberation in the liberal democratic tradition, motivated by an underlying commitment to humanism and anti-authoritarianism. We establish Rorty's relevance to modern slavery by looking at his historicist understanding of slavery and his concern for the underrepresented voices in our communities. To highlight the relevance of Rorty's pragmatism to current debates in business ethics, we also examine his views about moral sentiments, agency, and pragmatic deliberations. In the final section of the article, we critically engage with selected features of Rorty's approach and highlight opportunities for future work at the intersection of Rortian pragmatism and business ethics.

\section{PRAGMATISM AND RORTY'S PROJECT}

Broadly speaking, pragmatists believe that theoretical insight is of practical value when it engages with the real world, in a particular place and time. Knowing the world, in this philosophical tradition, is inseparable from one's agency within it (Legg and Hookway 2019). This general idea has attracted a variety of interpretations. Despite ongoing and at times contentious disagreements, pragmatists have a shared aim: for them, philosophical concepts are linked to practice so that theorizing must be useful as opposed to corresponding to some transcendental, mystical notion of truth; practice serves as a source of social norms, in contrast with philosophical traditions that locate the source of morality in strictly abstract principles; and finally, beliefs must stand up to experience 
and argument, as opposed to having a permanent metaphysical certainty, and are therefore fallible, namely, they can turn out to be false (Misak 2009).

Pragmatist thought had its beginnings in the United States in the 1870s. "Classic" pragmatism (e.g., Charles Sanders Peirce; William James; and, later, John Dewey, Jane Addams, and George Herbert Mead) focused on inquiry, meaning, and truth, before turning to politics, social improvement, and the community. Emancipatory projects were the practical end point of pragmatism, and early accomplishments demonstrated the usefulness of these ideas. Consider Jane Addams, who established the discipline of social work as an expression of pragmatist thought, or John Dewey's pioneering work in the philosophy of education. Pragmatism dipped in popularity and was challenged as analytic approaches in Anglo-American philosophy came to dominance after Dewey but was revived by Rorty in the 1970s, at a time when very few students of pragmatism remained.

In its contemporary form, pragmatism is an internationally recognized third alternative to, and middle ground between, the analytic and continental traditions in philosophy. A source of disagreement in debates on pragmatism concerns the notion of "truth." Based on their stance on truth, Rorty and the philosophers he influenced have been called "neo-pragmatists" (e.g., Hilary Putnam, Robert Brandom), in contrast to the "new pragmatists" (e.g., Cheryl Misak), who take truth and objectivity to have a different, more central position in philosophy, closer to what they see as the classic pragmatist ideals of Peirce. Given the temperature of critical debates about Rorty's work, using his approach as a way to motivate the study of pragmatism in business ethics may pose some risk. But there is good reason to do so, given disciplinary features within pragmatism itself.

Rorty single-handedly brought about a renaissance of pragmatism through a critique of mainstream epistemology's view that thought and language "mirror" (Rorty 1979) the world. In place of a preoccupation with philosophical puzzle generating and problem solving, Rorty is 
concerned with the historical genesis of philosophical tensions. He addresses fissures in philosophy not by problem solving but by problem dissolving (Ramberg 2013), using narration and redescription of actual empirical phenomena as his tools in place of thought experiments and hypotheticals. In comparison to the systematic philosophical approach of classic pragmatists like Peirce, Dewey, and even James, Rorty took on pragmatism as a largely therapeutic philosophical project that involves inventing new vocabularies and launching fruitful metaphors (Rorty 1979, 1991b). It was in this, and not its classic, systematic form that pragmatism was revived and then spread across the humanities and social sciences in the late twentieth century, animating debate on a range of topics. Linking Rorty's thought to business ethics is a nod in the direction of his historical role in invigorating pragmatic conversations and championing the social, public role of philosophy. It is also fitting given the dominance of the philosophical traditions he famously criticized within current normative debates in business ethics. Rorty's work offers a multifaceted, integrated view of pragmatism that ranges over an unusually wide intellectual territory, and pragmatists continue to build on Rorty's work as a matter of necessity in light (or in spite) of the controversies surrounding his views.

Rorty's first task was to challenge a specific, dominant philosophical stance on epistemology. His second task was to argue for gradual progress toward a liberal and pluralist global community. The first of these projects is critical and philosophical, the second, broadly speaking, political. We discuss these briefly before addressing Rorty's relevance to debates in business ethics.

\subsection{Critical Project}

Some business ethicists believe that a reasonable view about how things are in the world is constrained by objective knowledge about the nature of reality. We take some notion of truth or reality to be the benchmark for all metaphysical and epistemological inquiry that allows us (at least in principle) to know things about the world and to make some judgments. It is better to avoid subpar 
safety standards for workers on an international scale, irrespective of local laws and regulations, for example; better to avoid breaking the law or gaming regulations to increase profit irrespective of competitor practices; and better to refrain from forced labor, debt bondage, or human trafficking. Normatively inclined business ethicists seek to provide reasons that justify these kinds of claims. The descriptive/critically engaged take these claims to be implicitly true, at least at some level, and proceed to examine their features, manifestations, and ramifications. Many of us are motivated to study these claims because, on some level, we believe the claims to be true and to correspond to the way things really are or should be in the world.

Rorty does not think we believe the things we believe because they are "true." Instead, he thinks we might hold certain beliefs because they align well with our other beliefs, given our historically situated stance and the contextually specific norms in our community. He poses fundamental questions about what we can presume to know about the world and how that knowledge might inform our understanding. Instead of reasoned normative evaluations or critique, Rorty (2006a) engages with the question of moral progress in the liberal democratic intellectual tradition. This involves a criticism of the philosophical idea of knowledge as representation, and specifically knowledge as a mental mirroring of the mind-external world (Rorty 1979, 1991b, 1998c). Rorty's historicist skepticism questions the transcendental ambitions of traditional epistemology and metaphysics and the quest to provide "grounds" (Rorty 1979, 3) or reasons for knowledge claims. This involves rejecting the possibility of an ahistorical, neutral "God's-eye viewpoint" of reality. Instead, there is a plurality of views that over time gain social acceptance and acquire the status of norms because of their utility in a particular context, place, and time. For Rorty $(1979,3)$, interrogating the role of reason in the quest to find the ultimate and permanent objective notion of truth "underwrites or debunks claims to knowledge." This amounts to a complete rejection of the notion that an ideal vocabulary exists and that we can have hope in ideal concepts or mandatory 
forms of description (Rorty 1989). Rather, we should ask, what problem are we trying to solve, and what vocabularies are most useful for solving it?

Consider modern slavery as an example. Slavery and forced labor are enduring features of economic interactions. Workers' welfare (and the lack thereof) has not always been controversial or in conflict with prevailing social norms, however. Common intuitions aligned comfortably with slavery and slave-like practices in the past, and our beliefs and social norms change over time. According to Rorty, for those of us who disapprove of the inhumane global exchange of slaves today, this moral judgment need not correspond with truth or objective reality nor be grounded in or justified from a normative perspective. Rather, for Rorty, these practices might sit uncomfortably with our current (Western) notions about what we owe (or what we like to claim we owe) to members of our community. For him, there are no such things as obvious rights or wrongs to begin with, no "unchanging essences to be grasped, only new ways of describing both ourselves and the universe" (Rorty 2006a, 371). Consider Rorty's belief that Socrates was wrong: "we have not once seen the Truth, and so will not, intuitively, recognize it when we see it again" (Rorty 1982, xIii, emphasis original). When modern slavery takes forceful hold of our global supply chains—or "when the secret police come, when the torturers violate the innocent" (Stout 1988, 256)—Rorty believes there is nothing to be said to condemn these practices in general. This is an uncomfortable position, but live with it we must. This is not all that Rorty has to say on this topic, and we will set the stage shortly for Rorty's positive project and his case against slavery in his political writings. His antiPlatonist perspective is nonetheless noteworthy as it runs through his later political writings and has implications for a pragmatist business ethics.

Many philosophers have worried about Rorty's giving up on absolute values, and the same concern arises in business ethics. What can the pragmatist say about torture, for example (Stout 1988), and what of the morally forbidden range of practices in business, starkly exhibited by modern 
slavery? Rorty discussed this kind of objection in relation to the historical phenomenon of slavery in his address at the Society for Business Ethics (SBE) annual meeting in 2005: "doubting the existence of something transcultural and ahistorical that can provide guidance for moral choice [involves] denying the existence of absolute values. But we know that slavery [is] absolutely, objectively, wrong” (Rorty 2006a, 371). In response to this objection, Rorty explains that "adding 'absolute' to 'wrong' or 'objective' to 'truth' is an empty rhetorical gesture. It is just a way of pounding on the podium" (371). For Rorty, debates about torture or slavery cannot be settled through arguments about their absolute wrongness. Rather, we must work to make sense of them in relation to our moral sentiments and social norms and by engaging and deliberating about them alongside members of our communities.

Many have taken Rorty's position to entail a form of relativism. These critics see Rorty as dangerous, robbing the role of reason from pragmatism and, in turn, from philosophy. Rorty is not a relativist, however, because of his anti-representationalism (Rorty 1991b). Rorty criticized the correspondence theory of truth and philosophical projects that draw a line between "what is made and what is found, what is subjective and what is objective, what is mere appearance and what is real" (Ramberg 2009). His stance is not that these conceptual contrasts are useless but rather that they are always "context and interest bound" and that there is "nothing to be said about them in general" (Ramberg 2009). Rorty's commitment to a conversationalist view of knowledge is distinct from relativism and even subjectivism, in short, because these positions presuppose the distinctions he intends to reject. He does not prioritize the subjective over the objective, and his view decidedly rejects commitment to a relativist conception of truth or knowledge (Rorty 1991b, 1998c). To appreciate Rorty's notion of usefulness, we need to consider the relation between philosophy and politics in Rorty's positive project.

\subsection{Conversational Pragmatism}


In his positive project, Rorty characterizes intellectual culture in the absence of the governing metaphors of mind and knowledge. He argues that we should "see knowledge as a matter of conversation and of social practice, rather than as an attempt to mirror nature" (Rorty 1979, 171). According to this view, approaches to describing the world (scientific practices and everyday observations alike) should be seen as useful "tools" that help us get along rather than as true or false representations of the real world. Rationality is in turn best explained "by reference to what society lets us say, rather than the latter by the former" (Rorty 1979, 174). Language and vocabularies in this perspective are tools that should be evaluated in relation to the purpose they serve, as opposed to their propensity to uncover truth or represent reality (Ramberg 2009). And insofar as vocabularies are tools, they are subject to teleological assessment (Ramberg 2009) so that they can be ranked against one another depending on their usefulness. Clarifying the meaning of hypotheses by tracing their practical implications for particular experiences in specific situations is a longstanding pursuit among pragmatist thinkers. Rorty takes this same approach, but his stance on truth subjects knowledge to a singular constraint-conversations (Rorty 1998c, 2007b). We decide what is useful based on our encounters with one another within our communities. Knowledge claims are in turn constrained by the historically situated norms of particular communities. In this manner, Rorty (1998c, 57) sought "to move everything over from epistemology and metaphysics into cultural politics, from claims to knowledge and appeals to self-evidence to suggestions about what we should try."

Even for friendly critics who share Rorty's interest in pragmatism and historicist skepticism (e.g., Hilary Putnam), the view that there are no constraints on knowledge save for conversational ones is controversial (see Rorty 1998c). But Rorty had specific motivations for adopting this approach, and these motivations are relevant to interpreting his relevance to business ethics: he wanted to lose the distinction between philosophical explanation, on one hand, and understanding 
or interpretation, on the other hand. Crucially, he believed the cash value of losing this distinction is "a safeguard against reductionism" (Rorty 1991b, 109). As he put it,

by getting rid of the idea of "different methods appropriate to the natures of different objects" ... one switches attention from "the demands of the object" to the demands of the purpose which a particular inquiry is supposed to serve. The effect is to modulate philosophical debate from a methodologico-ontological key into an ethico-political key. For now one is debating what purposes are worth bothering to fulfil, which are more worthwhile than others, rather than which purposes the nature of humanity or of reality obliges us to have. For antiessentialists, all possible purposes compete with one another on equal terms, since none are more "essentially human” than others (Rorty 1991b, 110).

This concern with "humanity" and an anti-authoritarian rejection of objects and ideas in favor of practice and purpose motivate Rorty's view about abstract philosophical concepts and language, as well as politics. He believes we have a choice and bear responsibility for our vocabularies, and this same idea informs his views about democratic engagement and politics. For the Rortian business ethicist, this same shift from questions about ontology and epistemology to a humanist, ethicopolitical approach can inform the conversations of responsible business.

\section{RORTY, BUSINESS ETHICS, AND MODERN SLAVERY}

With an overview of Rorty's philosophical view in hand, we now turn to fleshing out specific features of Rorty's view that are especially relevant to business ethics and modern slavery. To begin, we discuss Rorty's view about politics.

\subsection{Politics}

In the preface to his final volume of Philosophical Papers, Rorty (2007b) puts forward his conception of philosophy as "cultural politics" and identifies the "principal assignment" (ix-x) of philosophers as contributing "to humanity's ongoing conversation about what to do with itself" 
(21). This is a decidedly public role for philosophers with a focus on morally progressive action, as opposed to abstract theorizing and problematizing. During this same time, he directed his attention toward issues of social and political justice with an international scope (e.g., feminism, human rights, globalization, and global justice) and wrote about his "hopes for a global, cosmopolitan, democratic, egalitarian, classless, casteless society” (Rorty 1999b, xii). We interpret Rorty's political work, expressed in his later writings and lectures (Rorty 1989, 1991a, 1991b, 1997a, 1997b, 1998a, 1999a, 1999b, 2000, 2006a, 2007a, 2007b), as a direct extension of his positive project on conversational pragmatism and his critical project on epistemology. We are not alone in making this interpretation (see Bernstein 2010; Brandom 2011; Ramberg 2009, 2013; Voparil 2011, 2014; Voparil and Bernstein 2010). And yet while the link between Rorty's philosophical and political projects is relatively well established among Rorty scholars, the implications of this link remain underappreciated among business ethicists.

The key imperative in Rorty's political approach is building and expanding the conditions for human solidarity within one's community. Rorty's political view is devoid of traditional philosophical and metaphysical commitments to universal principles and truth, in part because he worried that oppressive, reductionist forms of illiberalism would be smuggled in with preconceptions about "theory." For him, pragmatism has an important role to play in the transition toward a humanist society. As he put it, "there is no authority outside of convenience of human purposes that can be appealed to in order to legitimate the use of a vocabulary. We have no duties to anything nonhuman" (Rorty 1998a, 127). Liberal culture can therefore "take pride in its ability to increase the freedom and openness of encounters, rather than in its possession of truth" (Rorty 1991b, 2).

Rorty was skeptical of radicalism and of approaches aimed at uncovering systematic causes of injustice and exploitation (Rorty 1989, 1991b, 1998a). Instead of proposing sweeping changes to 
set everything right, he believed in piecemeal reforms that advance economic justice and enhance individual freedom (Ramberg 2009). For him, the commitment to liberal democratic freedoms in political solidarities is a historical contingency in Western culture. Rorty $(1989,196)$ reminds us that "we should stay on the lookout for marginalized people-people whom we still instinctively think of as 'they' rather than 'us."' He believes we should perpetually try to enlarge the scope of our community and that we do this by "regarding other people, or cultures, as members of the same community of inquiry as ourselves" (Rorty 1991b, 38).

To find new "possible conversation partners" (Rorty 1991b, 203), Rorty calls for an expansion of the "logical space necessary for moral deliberation" (Rorty 1991a, 3) to include unrecognized claims to injustice so that "a voice saying something never heard before" can come to the fore (1998c, 202). Encountering slavery in global supply chains calls for precisely such a recognition. For Rorty (1998c, 203), this involves rejecting the assumption that "all the logical space necessary for moral deliberation is now available — that all important truths about right and wrong can not only be stated but be made plausible, in language already at hand.” Instead, he calls for the use of "non-logical" means, such as new metaphors, and argues that individuals partaking in conversation promote their cause through "redescription" rather than argumentation. Redescription involves a change in "what we perceive as interesting truth value candidates resulting from acquiring new vocabularies” (Ramberg 2009), as opposed to a dominance of right over wrong or true over false in a systematic philosophical argument (Rorty 1989). The hope is that through redescription, we may come to appropriately change our beliefs with the goal of developing solidarity and expanding the scope and depth of our liberal democratic community. As Rorty (1991b, 38) puts it, "what we cannot do is to rise above all human communities, actual and possible." We now turn to the select instances where Rorty himself attends to the relevance of pragmatism to business ethics, starting with his invited address at the 2005 SBE annual meeting. 


\subsection{Rorty at the Society for Business Ethics Annual Meeting}

Rorty (2006a, 370) begins his SBE address by highlighting what he sees as a dominant question in modern times: "how can we create a better world for our descendants to inhabit," given our awareness of "the possibility for radical historical change" and our "increased tolerance for human diversity"? Rorty argues that it would be futile to study this question and the history of philosophy "in isolation from social, political, and economic history" (375, emphasis added). In a departure from his earlier political writings, he openly recognizes the importance of capitalism in his SBE address: "Nobody now doubts the need for market economies" (375). And yet Rorty remains concerned about the "unfairness produced by the operation of those markets," which he believes is just as "appalling" today as the conditions that drew Marx to envisage a communist utopia (378).

Rorty's negative project-his critical diagnosis of the defining projects of modern philosophy - is at the center of his political work and, by extension, in his views about business ethics. He views the contemporary labor landscape as intricately related to its historical development: he worries that the "horrors described by Dickens and Zola are still with us" and that “jungle capitalism" confirms that Marx is still correct, a hundred years later, to describe "the history of the human race [as] the history of class struggle" (Rorty 2006a, 379). Nonetheless, echoing his political project, he expresses hope for the future of business:

I hope that now ... at least a few executives of the great multinational corporations are thinking about the need to create a global economy that will, far down the road, make possible global social justice. These men and women are the people with the best sense of the directions in which economic forces are presently driving the nations, of where the real levers of power are to be found, and of the possibilities that remain open for both governments and business enterprises. If none of them are dreaming up idealistic, utopian scenarios for the formation of a morally decent global society, it is unlikely that such a 
society will ever come into existence. Perhaps the business ethics community will provide an environment in which such dreams are encouraged (379).

This passage lays out Rorty's position on the relevance of pragmatism to business ethics: for him, there is scope for pragmatic conversations within global contemporary markets; he conceives of a decidedly political role for business leaders in relation to governments; and he has hopes that conversations in business ethics can lead to a utopian, idealistic, morally decent society.

Rorty's address prompted extensive comments from and discussion by those attending the SBE meeting. A shared feature of prominent responses by De George (2006), Koehn (2006), and Bowie (2013) is a critical focus on Rorty's philosophical project and his stance on epistemology. This is not surprising. Indeed, at the time he delivered his address, an extensive body of research in philosophy, humanities, and social sciences had been engaging with the controversial features in Rorty's philosophical approach for nearly two decades. Familiarity with Rorty's antirepresentationalism and anti-essentialism, and his place in the history of pragmatism, motivates further engagement with his views on the part of business ethicists. Instead of starting with philosophy and "applying" ethical theory to business practice, Rorty begins with the empirical phenomenon and aims for the practical goal of solidarity. His motivations for doing so are humanist and anti-authoritarian - the same underlying themes in his views about truth, knowledge, reality, and language. Rorty's political writings are most fruitfully read through the lens of his earlier work, and the same is true about his relevance to the field of business ethics. His approach to pragmatism inspires a move from strictly theoretical thinking to practical thinking about business ethics, with a focus on solidarity and community. This switch from the philosophical to the practical, ethicopolitical key (Rorty 1991b, 110) is merited, given its potential for improving the plight of those in harm's way in corporate structures in general and modern slavery regimes in particular. Rorty's brand of pragmatism and his giving up on metaphysical comfort (Wicks 1993) involve a considered 
view about philosophy as a handmaiden of a humanist politics (Ramberg 2009). This approach to philosophy must be first and foremost fit for a purpose and useful. Echoing his political project, Rortian conversations in business ethics can be guided by this same subordination to usefulness over truth, objectivity, or normative justification.

Three additional features of Rorty's view have interesting implications for work in business ethics. These features were hinted at in passing during Rorty's SBE address, but, as we are about to show, they can benefit from being unpacked in relation to Rorty's body of work.

\subsection{Moral Sentiments}

Why should business ethicists take modern slavery seriously? One way to address this question involves examining moral obligations, for example, special obligations arising from corporate roles or general moral obligations owed to the slave laborer. This moral status is sometimes justified through respect for autonomy or rational capacity or based on the promissory nature of contractual agreements. Instead of focusing on theoretical principles and reasoned justifications, Rorty emphasizes the role of moral sentiments. In his SBE address, he takes a "historicist, anti-Platonist view of moral progress" and admits to being "dubious about the idea that moral theory can be more than the systematization of the widely shared moral intuitions of a certain time and place” (Rorty 2006a, 369). In relation to the slave laborer, Rorty $(1979,190)$ believes we have a moral responsibility as a matter of recognition within our community—as "a courtesy extended to potential or imagined fellow-speakers of our language.” We must prioritize sympathy for community members, "putting politics first and tailoring a philosophy to suit” (Rorty 1991b, 178). Notice that intuitions are at the core of this approach to relational priority. In place of reasoned and systematic moral considerations, Rorty believes we need imaginative sympathy with others, which we establish through conversations. In place of theory, Rorty (1989, xvi) relies on narrative, ethnographies, journalist reports, comic books, and novels to inform our sentimental 
education. The goal is to make moral identities more inclusive and expand what we mean by our kind of people. As he puts it, "everything turns on who counts as a fellow human being" (Rorty 1999a, 124). We may even need new vocabularies to replace older ones that did not appropriately capture our intuitions as we continuously reconsider and recreate ourselves and our expanded notion of community.

Let's consider our intuitions about modern slavery. Contemporary consumer habits are a reflection of our everyday moral intuitions about modern slavery. Most of us know that something somewhere in global supply chains is not quite right. We know about the size and astounding growth of the fast fashion and electronics contract manufacturing industries that can thrive on slavelike conditions, for example. Nonetheless, our consumption habits continue to sustain global supply chains in their current form. We might share certain common intuitions about workers' rights and welfare in the West, but the growth of slave labor amid thriving contemporary world markets does not give most of us pause.

Bowie (2013) observes that this evidence seems to work against Rorty—-that intuitions and sympathies alone appear not to be sufficient for motivating consumer responsibility. De George $(2006,383)$ also questions the assertion that "all one needs are moral intuition and moral imagination." He wonders about the sources that inform our moral intuitions and argues that intuitions must often be challenged, not accepted. ${ }^{1}$ Other business ethicists who write about human rights violations may further argue that modern slavery should be viewed as categorically morally problematic, irrespective of anyone's intuitions or sympathies.

\footnotetext{
1 The business ethicist whose work Rorty championed during his address is Patricia Werhane (Rorty 2006a, 375-76). This is to be expected given the central role Werhane assigns to moral imagination and intuitions in her work on business ethics. Nonetheless, Werhane and Rorty differ on their views about the role of reasoning in the development of moral imagination (Werhane 1999, 2006).
} 
Here is how a reply to these criticisms might go, informed by an understanding of Rorty's philosophical and political views: Rorty's anti-representationalism and anti-essentialism entail a historicist skepticism toward the analytic philosophical fixation on moral obligations and rights, their justification, structure, and content. For Rorty, if our aim is to change consumer habits, then we must try to inform our intuitions by familiarizing ourselves with the plight of slave laborers and developing loyalty toward them as members of our community. These better-informed intuitions can guide us as we enlarge our community, adopt new vocabularies, and develop solidarity toward each other. Rorty (1999a) makes this position explicit in his essay "Human Rights, Rationality, and Sentimentality," where he notes that the solution to human rights violations is not a better understanding of truth or a more convincing delivery of universal moral principles. Rather, cultural politics and an appeal to sentimentality are our only hope:

The best, and probably the only, argument for putting foundationalism behind us is the one I have already suggested: It would be more efficient to do so, because it would let us concentrate our energies on manipulating sentiments, on sentimental education, so that [people] are less tempted to think of those different from themselves as only quasi-human. The goal of this manipulation of sentiment is to expand the reference of the terms "our kind of people" and "people like us" (122-23).

Rorty's teleological take on pragmatism is in full view here-we should concentrate on moral sentiments because this would more efficiently achieve an expanded sense of moral community. This focus on pragmatic consequences goes hand in hand with his critical stance on the limits to reason giving and philosophical justifications. The benefit of narrative as opposed to theory is that it manipulates sentiments by getting us to imagine ourselves in the shoes of the oppressed.

In response to business ethicists who question his reliance on intuitions, then, Rorty (2006c, 413) explains that moral principles "have no force that is not borrowed from the intuitions they 
summarize ... moral progress occurs, only when we say something like 'Our moral principles have to be adjusted so as to make a place for our new intuition."' This does not mean that reasons do not have a role in business ethics thinking and in relation to modern slavery. Rather, for Rorty, reason giving is merely "one rhetorical strategy among others" that helps us "convince people that they should change their ideas about what constitutes injustice" (Rorty 2006c, 413). This also has implications for business ethics pedagogy. Instead of teaching her students about the trolley problem, deontology, and utilitarianism, the Rortian business ethicist arranges field trips outside the classroom to converse with local laborers and assigns novels and ethnographies on the contemporary and historical experiences of slavery from around the world.

Rorty's views about the priority of intuitions over moral reasoning were a controversial feature of his SBE address. And yet recent research on the role of intuitions in moral judgment has functioned to lend considerable support to Rorty's emphasis on moral intuitive capabilities. Indeed, while the cognitive-development nature of morality has long been studied as a system of abstract rules, there has been a profound shift in the years since Rorty's death in research on the psychological features of moral sentiments toward a conception of moral emotions and moral intuitions that are not anchored in reasoning (e.g., Greene and Haidt 2002; Haidt 2001; Rozin et al. 1999). This literature demonstrates widespread heuristic tendencies that tend to distort reasoned judgments, questioning the assumption that moral reasoning necessarily precedes or justifies moral sentiments (see also Kahneman and Sunstein 2005; Gazzaniga 2005, 2009; Gigerenzer 2007).

\subsection{Agency}

Among the most valuable features of a Rortian business ethics is his pragmatist stance on agency. By definition, an agent has the capacity to act, and his or her agency denotes the exercise of this capacity. For pragmatists, knowing the world is inseparable from one's agency within it, and for Rorty, being human and taking others' humanity into account are key concerns. His stance on 
epistemology entails a distinctive approach to accounting for this humanity. Specifically, Rorty $(1979,363)$ situates “objectivity, rationality, and normal inquiry" within a larger program of education and interaction that involves engaging with new conversation partners. The possibility of what Rorty calls "abnormal discourse" offers an important space of freedom and is expressed conversationally, that is, in our description as "choosers of alternative vocabularies" (Rorty 1979, $379)$ as opposed to mere responders. As Ramberg $(2008,444)$ puts this point, the more we treat ourselves as subservient responders, mere representers of structures or contents that are determinately there irrespective of our interested interaction with them, the more we abdicate our potential for personal, social, and political creativity, for freedom. A noteworthy feature of this freedom to act—-this agency-is its moral overtones. Rorty (1979, 385) criticizes the epistemology-centered approach to philosophy for its attempts to see justification as "hooked on to something which demands moral commitment—Reality, Truth, Objectivity, Reason." The problem with that view for Rorty is that if we see truth as a necessity, "then we should no longer have the responsibility for choice among competing ideas and words, theories and vocabularies" (375-76). Rorty's aim is instead to call attention to the crucial questions of choice and responsibility that underlie and are "pre-empted by the tacit and 'self-confident' commitment to the search for objective truth" (382).

In place of a focus on the attainment of "truth as a matter of necessity" (Rorty 1979, 376), Rorty (1998c, 83) offers a vision of “taking other human beings seriously.” Rorty was thus concerned with calling attention to "questions that are a matter of moral choice and cannot be decided by theoretical reflection or philosophical argumentation" alone (Voparil 2014, 84). This involves an explicit "attempt to call attention to the moral and political space within which choice occurs" and to locate ourselves "in this space" (Voparil 2014, 84). 
Under this conception of agency, Rorty's political writings on moral progress are best understood as a "project of directly confronting ourselves and our practices in ethical and political terms" (Ramberg 2009, 445). This is because giving up on what Rorty $(1979,368)$ calls the "project of universal commensuration" creates space, but also a choice/agency that requires responsibility. Rorty $(1961,311)$ calls this an "ethic of controversy," which is "not a 'substantive' ethics, for it would not tell a man which arguments to propound, but rather a 'formalist' ethics which would tell him what his responsibilities were to any arguments which he found himself propounding."

To consider modern slavery, instead of concerning ourselves with the distinctions between one set of deontic constraints over another, and instead of debating the grounds or source(s) for moral concerns surrounding moral obligations, Rorty's ethic of controversy calls on business ethicists to take our fellow human beings morally seriously. This is a deceptively simple stance. The theorist, the consumer, the business manager, the laborer, are all participants in this conversation and bear a responsibility. To take each other seriously is to take into consideration each others' interests and voices, including the underrepresented voices, and to formulate decisions “consensually, as a community" (Rorty 1998b, 3). Rorty calls for a radical reconsideration of our relations and our communities in the first instance, with any respective revisions of relevant structures and systems to follow. This liberal utopia entails limits on the exercise of authority and safeguards against totalitarianism. Rorty does not explicitly discuss contemporary corporate structures, global supply chains, or regulatory regimes, but his philosophical and political vision of hope and solidarity is decidedly utopian, so much so as to render modern slavery inconceivable.

\subsection{Pragmatic Deliberation}

A final feature of Rorty's pragmatism that is relevant to the modern slavery phenomenon involves deliberation in the liberal democratic tradition. Can Rorty be considered a deliberative democrat? Given the classic pragmatist tradition that inspired Rorty (e.g., Dewey), and given the 
political thinkers with whom he engaged (e.g., Rawls, Habermas), ${ }^{2}$ Rorty may be seen as participating in the tradition, or at least the conversation, of deliberative democracy. After all, he held considered views on democratic engagement in society and a distinctive position on argument, discourse, practices of justification, and the use of persuasion for convincing others about particular beliefs (Dieleman 2017). Nonetheless, there are good reasons to doubt that the label of deliberative democracy should be applied to Rorty's cultural politics, not least because of his emphasis on the role of moral sentiments as opposed to moral reasoning (Dieleman 2017). Rorty's use of metaphor and redescription suggests that he is not interested in the exchange of reasoned justifications supported by relevant evidence within democratic arenas. Furthermore, instead of helping us reach a common ground and arrive at some notion of truth, Rorty believes argumentation can convince us to adopt a new belief from among a set of existing candidate beliefs. The task of Rorty's redescription is in turn to offer new candidate beliefs that change the existing epistemic norms around what counts as acceptable reasons (Ramberg 2009).

Rorty's view on rationality poses another barrier to thinking of him as a deliberative democrat. Consider his stance on rationality in his discussion of justice and loyalty. He explains that justice and loyalty have different sources—reason and sentiment, respectively—but then proceeds to offer an account that merges reason with sentiments so that "being rational and acquiring a larger loyalty are two descriptions of the same activity" (Rorty 1997a, 145). To advise people to be rational is thus "to suggest that somewhere among their shared beliefs and desires there may be enough resources to permit agreement on how to coexist without violence” (145-46). Rorty's account of rationality in this pragmatic interpretation of Rawls's overlapping consensus (Bacon 2008; Mouffe 1993; Wicks 1990) may be seen as clashing with standard takes on deliberative democracy, although

\footnotetext{
2 Rorty engages with Rawls's work in "Justice as a Larger Loyalty" (Rorty 1997a, 42-55) and "The Priority of Democracy to Philosophy” (Rorty 1991b, 175-96). See also his exchanges with Habermas in Niznik and Sanders (1996).
} 
that is not how Rorty would see things. A dominant theme in business ethics work on the normative role, structure, and nature of deliberative democracy is influenced by a Habermasian notion of discourse and infused by a Kantian view of rationality. Rorty warns against this "stronger, more Kantian" notion that would suggest "being rational guarantees a peaceful resolution of conflicts" (Rorty 1997a, 146). He also warns against the view that "if people are willing to reason together long enough," then the "force of the better argument" will lead participants to concur (146). Rorty is skeptical of the notion that a "better argument" exists and raises doubts about a "natural, transcultural relation of relevance which connects propositions with one another" (146). Denying such a natural order makes way for Rorty's pragmatism about deliberations, since, as he puts it, “one can only evaluate arguments by their efficacy in producing agreement among particular persons or groups" within a finite space and time (146). His vision of anti-authoritarian cultural politics thus abandons the conception of reason that many deliberative democrats take as pivotal in business ethics.

Habermas $(2000,50)$ worried that Rorty's account lacks “a suitable equivalent for an orientation towards truth" that provides a "rational motive for expanding the circle of members" in a community of justification. In response, Rorty wondered whether orientation toward truth and universal validity necessarily carry out the important tasks of self-creation and redescription. For Rorty, truth can be a "useful” idea, but it won't necessarily get us from "a commitment to justification to a willingness to submit one's belief to the inspection of any and every language user" (Rorty 2000,17). Rorty wishes to expand the size of the competent audience for deliberation to “include those not previously regarded as conversation partners" (Voparil 2014, 95). For this purpose, he turns toward a "historically contingent sense of moral identity" (Rorty 2000, 61), "curiosity," that is, "the urge to expand one's horizons of inquiry" (17), and the "social virtues" of "conversability," "decency," "respect for others," and "toleration" (62). These are the virtues that 
inspire "the slave-owner to listen to the slave" (62, emphasis added). With these virtues in hand, in his later writings, Rorty engages with a group of individuals he called the "radically situated." In his “The Priority of Democracy to Philosophy" (Rorty 1991b, 175-96) and in "Pragmatism as Antiauthoritarianism" (Rorty 2006b), Rorty described moral progress as "a history of making rather than finding, of poetic achievement by 'radically situated' individuals and communities, rather than as the gradual unveiling, through the use of 'reason,' of 'principles' or 'rights' or 'values”' (Rorty 1991b, 182, 189).

Empirical work on modern slavery details the conditions and contexts that make slave workers decidedly radically situated: an estimated 40.3 million people work under conditions of modern slavery around the world (GSI 2018). Most slave labor involves menial work in electronics, agriculture, fishing, mining, brick making, and garment industries (Bales 2016; Bales and Trodd 2013). A growing body of social scientific research examines modern slavery as an urgent societal problem in global capitalist markets (e.g., Bales and Soodalter 2010; Donaghey et al. 2014; Feasley 2016; Kittinger et al. 2017; Kotiswaran 2017; LeBaron 2014; Quirk 2006; Ramasastry 2002; Strauss 2012).

To appreciate the empirical context of modern slavery, we now consider some details about slave labor in the fisheries industry (Bonfanti and Bordignon 2017; Marschke and Vandergeest 2016; Österblom 2017). Slavery is universally illegal and explicitly prohibited in global agreements, such as the 1926 Slavery Convention and the United Nations Convention on the Law of the Sea; nevertheless, it is a relatively widespread phenomenon. A recent report by the Environment Justice Foundation describes slavery, human trafficking, forced confinement, debt bondage, assault, and murder aboard fishing vessels from eleven countries operating across three oceans, spanning developing and developed nations from the European Union and United States to Asia and South America (Environmental Justice Foundation [EJF] 2019). There have been modern slavery 
investigations of fishing crews in Thailand, Taiwan, and South Korea (International Organization for Migration 2016; EJF 2019), and fisheries workers have become victims of trafficking and bonded labor, exploited by brokers, tricked into the fishing industry, or stranded on boats in Cambodia, Indonesia, Myanmar, the United Arab Emirates, and Spain (EJF 2019). Hawai'i serves as a hub for 140 US-flagged longliner fishing boats, where forced and unpaid labor and living conditions akin to slavery have been documented among 600-700 workers (Natural Resources Committee 2016; Mendoza and Mason 2016). In New Zealand waters, modern slavery has been documented among vessels under charter for months at a time, hundreds of miles offshore (Skinner 2012; Stringer, Whittaker, and Simmons 2016). Human trafficking and slave labor have also been reported on domestic vessels across British and Irish fisheries (Lawrence and McSweeney 2017; Migrant Rights Centre Ireland 2017).

Modern marine fisheries require twice the fishing effort of the 1950s to catch the same amount of fish, leading to serious labor abuses that exploit vulnerable workers in an effort to reduce costs in this "race to fish" (Tickler et al. 2018). The global trade patterns governing seafood pose further issues: seafood is the world's most widely traded food commodity (Bellmann, Tipping, and Sumaila 2016). It involves complex supply chains, with chains of custody that pass through numerous intermediaries and countries before reaching our dining rooms. Even before the fish enter the supply chain, traceability issues can arise because of routine "transshipment" in distant-water fishing operations, whereby catches of multiple fishing vessels are combined before the catch lands, making it impossible to trace fish back to particular vessels (Ewell et al. 2017). Seafood caught using modern slavery practices can thus be effectively "laundered" by "combining it with legally caught fish in subsequent processing steps" (Tickler et al. 2018, 2). About 32 percent of wild-caught fish that is imported into the United States is estimated to have been caught illegally (Pramod et al. 2014) and can therefore involve exploitative labor practices. Governments and nonprofit organizations 
have begun to deploy resources and expertise to improve labor practices in marine fisheries, but corporations, demand, and consumer markets increasingly play a role as well.

The empirical context of modern slavery in marine fisheries underscores the importance of a useful approach to business ethics_one that aims to curtail the slaves' suffering and build solidarity between consumers and the modern slaves working on vessels off our shores. Through such an approach, we can not only study the economics of marine fisheries and the structure of global fisheries supply chains but, just as importantly, examine the social norms and related moral intuitions that sustain the production, exports, and global trade of seafood. We can understand where and how slavery thrives in marine fisheries, take note of our own freedom to act as consumers who choose to sustain this system, and ponder our willingness to deliberate and engage in conversations about this phenomenon. We may observe that the extreme labor abuse in contemporary fisheries take a different shape and form than the historical notion of chattel slavery and that it therefore deserves an alternative vocabulary. Alternatively, we might choose to use the term slavery as we work to describe, redescribe, and make sense of our role in global efforts to deliver the fruits of the sea to our plates. Rorty's pragmatism and his position on moral sentiments, agency, and deliberation thus offer a useful approach to business ethicists who care to engage with the problem of modern slavery and work toward moral progress in labor standards across global supply chains.

\section{CRITICAL DEBATES}

We turn next to a critical engagement with Rorty's writings at the intersection of business ethics and pragmatism. This section has two parts. First, given Rorty's engagement with the liberal democratic tradition, his political view is relevant to ongoing debates in business ethics about deliberative democracy. A second interesting area involves moving beyond arguing "Against Bosses and Oligarchs," the title of an interview Rorty gave in 1998, and beginning to examine the role of 
institutions. This is especially important for proponents of the stakeholder perspective, given the pragmatist features of stakeholder theory, and given the institutionally laden empirical context of business ethics. Relatedly, we discuss some of the opportunities for future pragmatist work in response to the modern institutional reality surrounding the gig economy and the fourth industrial revolution.

\subsection{The Risk of Deliberation}

Although Rorty's approach offers an attractive pragmatist alternative to engaging with the radically situated, more resources are arguably needed to make these conversations genuinely fruitful. The question is whether Rorty's account enables those outside our practices and beliefs to enter into conversations in a way that respects their differences. What we do not want is a caricature of the tolerant liberal who says "I am willing to accept individual differences-as long as you basically act and talk like me" (Bernstein 1996, 30). The worry is that Rorty's conviction that Enlightenment political vocabularies are historically contingent, and therefore pragmatically justified, could limit openness to the diverse perspectives that marginalized groups might offer. He takes seriously the concerns of new "oppressed minority" groups and celebrates "the emergence of feminism, gay liberation, various sorts of ethnic separatism, aboriginal rights, and the like” (Rorty 1999b, 235) (and movements against modern slavery might be added to this list). But he ultimately sees these as “add[ing] further concreteness to sketches of the good old egalitarian utopias" and a revision of old (Western) ideas about a just global society (235).

This makes Rorty at once committed to the possibility of "a voice saying something never heard before" (Rorty 1998c, 202), while at the same time holding that "the vocabulary of the 'twentieth-century Western social democratic intellectuals' may well be the best anybody has yet come up with" (Balslev 1991, 53). Indeed, Rorty retained an "ungrounded hope' that the best of the American liberal tradition of tolerance, individual freedom, and the demand for social equality would 
prevail” (Bernstein 2010, 200). But taking a problem like modern slavery seriously and being committed to democratizing the epistemological space in Rorty's anti-authoritarian pragmatism may require us to go further. Taking Rorty's grand "we," which seeks to subsume everyone under a shared moral identity, perhaps "we must be open to joining the conversations of others rather than asking them to join ours" (Voparil 2011, 125; see also Mouffe 1993, 2005; Young 2000). “The” conversations of global supply chains may need a new system of accountability given the social differences between conversation participants, the prevalence of marginalized voices, and the privilege of authoritative discourse. As Voparil (2011) puts this point, to understand difference, we need to be open and listen, but we also need to be open to claims upon us: "something of ourselves needs to be risked" (n. 36, emphasis added).

Understanding this risk in business ethics terms has interesting implications for the debate on deliberative democracy. With respect to the normative role of corporations, business ethicists have raised a number of convincing objections against deliberative democracy and its applicability to the corporation or to capitalist markets: critics have questioned not only the political role of the corporation as a participant in deliberations but also the corporation as a site of deliberation and the structures of firms and markets as boundaries of deliberation (e.g., Whelan 2012; Hussain and Moriarty 2018; Sabadoz and Singer 2017). Rorty offers an attractive alternative approach, given his rejection of the universalist epistemological foundations taken for granted in (largely Habermasian) deliberative accounts in business ethics. At the same time, the risks of such a conversation add to some of the instrumental issues surrounding deliberative democracy, for example, by being more costly than expected (or possible) for the standard corporate enterprise. Rorty's approach further poses new, arguably amplified normative problems, by clashing with existing market structures and international regulatory frameworks that govern economic systems and institutions. It is not immediately clear how and whether Rorty's project of redescription, his emphasis on moral 
sentiments, and his approach to deliberative democracy align with existing organizational and institutional processes in global markets.

\subsection{Beyond Bosses and Oligarchs}

In his call to "widen the circle of people who we think of as 'much like ourselves," Rorty (2006a, 376) envisioned not just new individual-level interactions but also "changes in institutions and practices that would serve the hitherto neglected needs of these newly enrolled members of our moral community." As he noted in his address at the SBE annual meeting, upon reading Uncle Tom's Cabin, "some plantation owners began asking whether the economy of the South might not survive the end of chattel slavery, and to envisage alternative modes of production" (Rorty 2006a, 377). He wondered whether "reading Dickens and Zola" might similarly inspire business leaders to "rethink their ideas about the relations of labor and management" (377). This same kind of consideration can inform the contemporary governance frameworks, institutions, and organizational forms that enable and sustain problems like modern slavery. Although Rorty's philosophical and political writings did not elaborate on the role of institutions, this is an area he clearly started to appreciate by the time of this address: he insisted that any project that does not bear on "whether and how to change our political and social institutions" would be "pointless" (Rorty 2006a, 375). We take this insight to subsume economic institutions, following Rorty's bundling of the "social, political and economic" realms in their relevance to the history of philosophy (375).

The humanist and anti-authoritarian features of Rorty's cultural politics, discussed in section 1 of the article, can guide future pragmatist business ethics work on institutions, including the procedural norms that guide community deliberations, government policy making, or corporate strategy development. The logical space of asking and giving reasons, of moral deliberation and social interaction, is intricately reliant on institutions. The challenge may well be that Rorty's (1999b, xii) utopian hopes for a "global, cosmopolitan, democratic, egalitarian, classless, casteless society" 
entail somewhat radical institutional implications. Social scientists, in comparison to philosophers, tend to work more extensively on institutions, so it would be useful to learn about Rorty's stance on social science. For a hint, we look to Rorty's interaction with Richard Posner, the jurist and economist who celebrated and was inspired by Rorty's pragmatism. Posner took issue with Rorty's detachment from the "strength of mid-level theories like economics" and the rejection of "facts" informed by social science (Posner 1993, 42-44). As Rorty explains, "Posner has always said that philosophically I'm on the right track, it's just that I had no sense of concrete economics or socioeconomic policy... [Posner says] 'Rorty is still talking about "oligarchy" and "the bosses." I want to use that... as a blurb for some book sometime" (Nystrom, Puckett, and Rorty 1998, 66). A few years later, Rorty explained, in a lecture titled "Dewey and Posner on Pragmatism and Moral Progress," that the problem with the "strength" of mid-level theories is their undivided, positivist preoccupation with fact and truth—a theme that (some) pragmatists worry might introduce the danger of reductionism (Rorty 2007a).

An important challenge of conceiving of liberal institutions in the logical space of reasons alongside bosses and oligarchs and other conversation participants is to facilitate a humanist engagement that is sensitive to specific contexts and particular human perspectives while at the same time being guided by appropriate procedural safeguards against totalitarianism. There are also questions for the Rortian business ethicist to consider here regarding the epistemological and ethical status of institutions, groups, and collectives in relation to moral sympathy and moral agency. Perhaps one solution is to focus on assertions made on the part of institutional representatives. Alternatively, institutional frameworks can be informed by procedural guidelines that are Rortyinspired, for example, by introducing skepticism about the universal validity and factual dedication of social scientific approaches (e.g., economics), which tend to dominate policy making and labor governance frameworks. 
Another challenge regarding institutions arises in a dominant approach in the field of business ethics that has been going through a "pragmatic turn" since the 1990s — the "stakeholder" perspective (e.g., Freeman 1994; Freeman et al. 2010). Some of the founding proponents of this view have long been building a pragmatist vocabulary that characterizes business as not necessarily a profit-making machine but rather a human enterprise. For these scholars, moving beyond bosses and oligarchs is a primary task for the future of the stakeholder approach. The implications of Rorty's work for this literature are considerable and merit separate treatment, so we do not allocate space here to their discussion and include only one observation: save for a few exceptions (e.g., Bowie 20133), business ethics critics of the stakeholder approach fail to acknowledge or engage with its pragmatist features. Part of the solution to this problem is for proponents to sharpen, and more forcefully articulate, the pragmatist philosophical backbone of stakeholder theory. These efforts will build on Rorty's work as a matter of necessity.

More generally, considering business ethics as an academic field, it is noteworthy that the preoccupation with "bosses and oligarchs" easily outweighs the focus on "workers" and the myriad institutional challenges they encounter. Moving beyond "the bosses" is thus an important challenge to the collective identity of the academic business ethics field. Business ethicists have dedicated considerable energy to raising questions about justice and fairness in relation to different kinds of organizational structures in national and international markets. And yet business ethicists have long aimed for the most part at traditional large corporations and the individuals who manage, lead, and own them. Ethical issues in governance, social responsibility, investment, marketing, employment, and manufacturing are commonly examined in relation to a unified organizational form and often with respect to the top-ranked individual decision makers. For the pragmatist business ethicist, Rorty's work offers powerful resources not just for criticizing "the boss" but also for questioning institutional features that affect workers at all levels and in a variety of organizational forms. 
This call to attend more carefully to modern institutions is especially important given the rise and dominance of the "gig" or "sharing" economy. The gig economy's growing army of workers and its new organizational forms and consumer culture have fundamentally changed business interactions and labor practice. How might business ethics inform and guide the development of the gig economy to accomplish its supposed goals of a democratic and sustainable economy? A range of ethical issues have received attention in court cases and the popular press in this regard, and business ethicists have a critical role to play in further informing these debates (see Etter, Fieseler, and Whelan 2019). Rorty's emphasis on the role of moral sentiments offers an important resource for thinking about gig economy workers (or employees) and their appropriate moral organizational status. And Rorty's conception of moral agency and responsibility places an ethical and political responsibility on each of us as business ethicists, consumers, workers, or bosses to interact with the gig economy responsibly. A Rortian business ethics would also involve dedicated engagement, loyalty, and solidarity with all those who constitute the gig economy in our communities.

A final noteworthy challenge for the Rortian business ethicist is the rise of the fourth industrial revolution and the impact of technological advances on the way we work and relate to one another. The purported goal of the fourth industrial revolution is to create an "inclusive and humancentred future," one that is delivered through "technology-driven change" (Schwab 2016). This is a utopian institutional project unfolding rapidly. The dominance of technology in our daily lives and our social interactions poses a challenge to the Rortian human-centred conception of business ethics. From morally responsible androids (see Donaldson 2019, 853) to ethical self driving cars (see Nyholm and Smids 2016), business ethicists face a new set of challenges to our conception of responsible business.

For business ethicists interested in engaging with technological changes and challenges, Rorty's anti-foundationalist, anti-essentialist, and anti-representationalist approach offers some 
timely ideas. The success, effectiveness, and socially beneficial nature of technological interactions depend on how they are perceived by the community. There is therefore a new, urgent need to attend to our moral intuitions about using novel technology as a means of everyday interactions. As Rorty $(1998$ a 127$)$ notes, there is "no authority outside of convenience of human purposes that can be appealed to in order to legitimate the use of a vocabulary. We have no duties to anything nonhuman." Thus, for Rorty, there is "nothing that we can rely on but ourselves and our fellow human beings" (Bernstein 2010, 211).

Given this Rortian guidance, insofar as the fourth industrial revolution requires safeguarding, guiding, and regulating through institutional responses, our intuitions about technology must play a pivotal role (as opposed to a secondary role following moral reasoning) in informing and developing these institutions. Second, insofar as technology can be a nonhuman source of authoritarian control, a pragmatist sense of moral agency involves taking on the responsibility of developing antitotalitarian institutions so as to guard the long-standing liberal traditions in our communities. This safeguarding exercise raises questions about the boundaries of what can appropriately be considered "our" community, of course. Rorty's views about global justice are beyond the scope of this article, but there is plenty of room for critical engagement with these features of his work.

\section{CONCLUSION}

This article offers an overview of Rorty's pragmatism, including his views about moral sentiments, his ethical and relational notion of agency, and his conversational approach to democratic deliberation. These insights offer opportunities for business ethicists to engage with practical, as opposed to strictly theoretical, thinking about modern slavery, not the least by highlighting our own responsibility to build solidarity with the modern slave and to improve the labor conditions in global industrial markets. Rorty explicitly engages with the historical phenomenon of slavery as a moral crisis, and he attends to labor conditions, underrepresented 
voices, and economic injustice in contemporary markets in his later writings (e.g., Rorty 1997a, 1998b, 1998c). Drawing on Rorty's use of "redescription" as opposed to argumentation, the term slavery is arguably a fitting trigger word for describing exploitative contemporary labor practices as we work to inspire sympathy for and solidarity with exploited workers in our communities.

While Rorty represents one (some say radical) end of the pragmatist spectrum on questions about truth, objectivity, knowledge, representation, and rationality, the diversity of interpretations among scholars of pragmatism entails other promising areas of research at the intersection of pragmatism and business ethics. Indeed, given that pragmatists are genuinely interested in the usefulness of their ideas, it is surprising that more have not already begun to write about the moral and political issues surrounding business practice. Many philosophers who write about business ethics are drawn to the field through an interest in, and engagement with, practice. Linking philosophical concepts to practice, emphasizing the usefulness of theory, locating the source of morality in practice as opposed to strictly abstract theory, and revising beliefs in light of experience and discourse/argumentation — these are themes that run through pragmatist thought and are bound to seem familiar to many business ethicists regardless of their alignment with Rorty's philosophical views. Many of us may have been working along these pragmatist lines in business ethics all along without realizing it.

\section{REFERENCES}

Arnold, Denis G., and Norman E. Bowie. 2003. "Sweatshops and Respect for Persons." Business Ethics Quarterly 13 (2): 221-42.

Bacon, Michael. 2008. Richard Rorty: Pragmatism and Political Liberalism. Lanham, MD: Lexington Books.

Bales, Kevin. 2016. Blood and Earth: Modern Slavery, Ecocide, and the Secret to Saving the 
World. New York: Spiegel and Graux.

Bales, Kevin, and Ron Soodalter. 2010. The Slave Next Door: Human Trafficking and Slavery in America Today. Berkeley: University of California Press.

Bales, Kevin, and Zoe Trodd. 2013. Addressing Contemporary Forms of Slavery in EU

External Policy. Briefing paper for the European Parliament's Subcommittee on Human Rights, December. http://www.europarl.europa.eu/RegData/etudes/note/ join/2013/433703/EXPO-DROI_NT(2013)433703_EN.pdf.

Balslev, Anindita Niyogi. 1991. Cultural Otherness: Conversations with Richard Rorty.

Shimla: Indian Institute of Advanced Study.

Bellmann, Christophe, Alice Tipping, and U. Rashid Sumaila. 2016. "Global Trade in Fish and Fishery Products: An Overview." Marine Policy 69 (July): 181-88.

Bernstein, Richard J. 1996. "The Hermeneutics of Cross-Cultural Understanding." In CrossCultural Conversation, edited by Anindita Niyogi Balslev, 29-41. New Delhi: Indian Institute of Advanced Study.

Bernstein, Richard J. 2010. The Pragmatic Turn. Cambridge: Polity Press.

Bonfanti, Angelica, and Marta Bordignon. 2017. "Seafood from Slaves: The Pulitzer Prize in the Light of the UN Guiding Principles on Business and Human Rights.” Globe Policy 8 (4): 498-504.

Bowie, Norman E. 2013. Business Ethics in the 21st Century. New York: Springer.

Brandom, Robert B. 2011. "Linguistic Pragmatism and Pragmatism about Norms: An Arc of Thought from Rorty's Eliminative Materialism to His Pragmatism.” In Perspectives on Pragmatism: Classical, Recent, and Contemporary, edited by R. B. Brandom, 107-15. Cambridge, MA: Harvard University Press.

Caruana, Robert, Andrew Crane, Stefan Gold, and Genevieve LeBaron. 2020. "Modern 
Slavery in Business: The Sad and Sorry State of a Non-field.” Business and Society.

DOI: $10.1177 / 0007650320930417$.

Crane, Andrew. 2013. “Modern Slavery as a Management Practice: Exploring the Conditions and Capabilities for Human Exploitation.” Academy of Management Review 38 (1): 49-69.

De George, Richard T. 2006. "The Relevance of Philosophy to Business Ethics: A Response to Rorty's 'Is Philosophy Relevant to Applied Ethics?”' Business Ethics Quarterly $16(3): 381-89$.

Dieleman, Susan. 2017. "What Would It Mean to Call Rorty a Deliberative Democrat?" Contemporary Pragmatism 14 (3): 319-33.

Donaghey, Jimmy, Juliana Reinecke, Christina Niforou, and Benn Lawson. 2014. "From Employment Relations to Consumption Relations: Balancing Labor Governance in Global Supply Chains.” Human Resource Management 53 (2): 229-52.

Donaldson, Thomas. 1989. The Ethics of International Business. New York: Oxford University Press.

Donaldson, Thomas. 2019. “Androids and Corporations: Why Their Rights Derive from Purpose." Georgetown Journal of Law and Public Policy 17 (Spring): 853-64.

Environmental Justice Foundation. 2019. Blood and Water: Human Rights Abuse in the Global Seafood Industry. https:/ / ejfoundation.org// resources/downloads/Bloodwater06-2019-final.pdf.

Etter, Michael, Christian Fieseler, and Glen Whelan. 2019. "Sharing Economy, Sharing Responsibility? Corporate Social Responsibility in the Digital Age." Journal of Business Ethics 159 (4): 935-42.

Ewell, Christopher, Sarika Cullis-Suzuki, Mikaela Ediger, John Hocevar, Dana Miller, and 
Jennifer Jacquet. 2017. "Potential Ecological and Social Benefits of a Moratorium on Transshipment on the High Seas.” Marine Policy 81 (July): 293-300.

Feasley, Ashley. 2016. “Eliminating Corporate Exploitation: Examining Accountability Regimes as Means to Eradicate Forced Labor from Supply Chains.” Journal of Human Trafficking 2 (1): 15-31.

Freeman, R. Edward. 1994. “The Politics of Stakeholder Theory: Some Future Directions.” Business Ethics Quarterly 4 (4): 409-21.

Freeman, R. Edward. 2012. "Bowie’s Ethics: A Pragmatist Perspective.” In Kantian Business Ethics: Critical Perspectives, edited by D. G. Arnold and J. D. Harris, 35-47. Cheltenham, UK: Edward Elgar.

Freeman, R. Edward, Jeffrey S. Harrison, Andrew C. Wicks, Bidhan L. Parmar, and Simone De Colle. 2010. Stakeholder Theory: The State of the Art. Cambridge: Cambridge University Press.

Gazzaniga, Michael S. 2005. The Ethical Brain. New York: Dana Press. Gazzaniga, Michael S. 2009. Cognitive Neuroscience. Cambridge, MA: MIT Press. Gigerenzer, G. 2007. Gut Feelings: The Intelligence of the Unconscious. London: Penguin. Global Slavery Index. 2018. Walk Free Foundation. https://downloads.globalslaveryindex. org/ephemeral/GSI-2018_FNL_190828_CO_DIGITAL_P-1618559969.pdf.

Gold, Stefan, Alexander Trautrims, and Zoe Trodd. 2015. "Modern Slavery Challenges to Supply Chain Management.” Supply Chain Management: An International Journal 20 (5): 485-94.

Greene, Joshua, and Jonathan Haidt. 2002. "How (and Where) Does Moral Judgment Work?" Trends in Cognitive Science 6 (December): 517-23.

Habermas, Jürgen. 2000. “Rorty’s Pragmatic Turn.” In Rorty and His Critics, edited by 
Robert B. Brandom, 31-55. Malden, MA: Blackwell.

Haidt, Jonathan. 2001. “The Emotional Dog and Its Rational Tail: A Social Intuitionist Approach to Moral Judgment.” Psychology Review 108 (4): 814-34.

Hussain, Waheed, and Jeffrey Moriarty. 2018. “Accountable to Whom? Rethinking the Role of Corporations in Political CSR.” Journal of Business Ethics 149 (3): 519-34.

International Labour Organization. 1930. Forced Labour Convention (No. 29). Geneva: International Labour Organization.

International Labour Organization. 2005. A Global Alliance against Forced Labour. Global report under the follow-up to the ILO Declaration on Fundamental Principles and Rights at Work. Report of the Director-General. Geneva: International Labour Organization. https://www.ilo.org/public/english/standards/relm/ilc/ilc93/pdf/rep-ib. pdf.

International Labour Organization. 2017. Global Estimates of Modern Slavery: Forced Labour and Forced Marriage. Geneva: International Labour Organization. International Organization for Migration. 2016. Report on Human Trafficking, Forced Labour and Fisheries Crime in the Indonesian Fishing Industry. Jakarta: International Organization for Migration.

Kahneman, Daniel, and Cass R. Sunstein. 2005. "Cognitive Psychology of Moral Intuitions.” In Neurobiology of Human V alues, edited by J.-P. Changeux, A. R. Damasio, W. Singer, and Y. Christen, 91-105. Berlin: Springer.

Kittinger, John N., Lydia C. L. Teh, Edward H. Allison, Nathan. J. Bennett, Larry B. Crowder, Elenea M. Finkbeiner, Christina Hicks et al. 2017. "Committing to Socially Responsible Seafood.” Science 356 (6341): 912-13.

Koehn, Daryl. 2006. “A Response to Rorty.” Business Ethics Quarterly 16 (3): 391-99. 
Kotiswaran, Prabha, ed. 2017. Revisiting the Law and Governance of Trafficking, Forced

Labor and Modern Slavery. Cambridge: Cambridge University Press.

Lawrence, Felicity, and Ella McSweeney. 2017. "UKPolice Rescue Nine Suspected Victims of Slavery from British Trawlers." Guardian, December 12. https://www. theguardian.com/world/2017/dec/12/uk-police-rescue-nine-suspected-victims-ofslaveryfrom-british-trawlers.

LeBaron, Genevieve. 2014. "Reconceptualizing Debt Bondage: Debt as a Class-Based Form of Labor Discipline.” Critical Sociology 40 (5): 763-80.

LeBaron, Genevieve, and Andrew Crane. 2019. "Methodological Challenges in the Business of Forced Labour." In Researching Forced Labour in the Global Economy: Methodological Challenges and Advances, edited by G. LeBaron, 25-43. Oxford: Oxford University Press.

Legg, Catherine, and Christopher Hookway. 2019. "Pragmatism.” In The Stanford Encyclopedia of Philosophy, edited by E. N. Zalta. https://plato.stanford.edu/archives/ spr2019/entries/pragmatism/.

Marschke, Melissa, and Peter Vandergeest. 2016. "Slavery Scandals: Unpacking Labour Challenges and Policy Responses within the Off-shore Fisheries Sector.” Marine Policy 68 (June): 39-46.

Mendoza, Martha, and Margie Mason. 2016. "Hawaiian Seafood Caught by Foreign Crews Confined on Boats.” Associated Press. https://www.ap.org/explore/seafood-fromslaves/ hawaiian-seafood-caught-foreign-crews-confined-boats.html.

Migrant Rights Centre Ireland. 2017. "Left High and Dry: Exploitation of Migrant Workers in the Irish Fishing Industry.” https://www.mrci.ie/2017/12/11/left-high-and-drytheexploitation-of-migrant-workers-in-the-irish-fishing-industry/.

Misak, Chantal. 2009. "Richard Rorty's Place in the Pragmatist Pantheon.” In The Philosophy 
of Richard Rorty, edited by R. E. Auxier and L. E. Hahn, 29-43. Library of

Living Philosophers XXXII. Chicago: Open Court.

Mouffe, C. 1993. The Return of the Political. New York: Verso.

Mouffe, C. 2005. The Democratic Paradox. New York: Verso.

Natural Resources Committee. 2016. "Natural Resources Democratic Forum: Fishing for Justice_-Slavery and Human Rights Abuses at Sea." https:// naturalresources.house. gov/hearings/_fishing-for-justice-slavery-and-human-rights-abuses-at-sea.

Niżnik, Józef, and John T. Sanders, eds. 1996. Debating the State of Philosophy: Habermas, Rorty, and Kolakowski. Westport, CT: Praeger.

Nyholm, Sven, and Jilles Smids. 2016. “The Ethics of Accident-Algorithms for Self-Driving Cars: An Applied Trolley Problem?” Ethical Theory and Moral Practice 19 (5): 1275-89.

Nystrom, Derek, Kent Puckett, and Richard Rorty. 1998. Against Bosses, Against Oligarchies: A Conversation with Richard Rorty. Charlottesville, VA: Prickly Pear.

Österblom, Henrik, Jean-Baptiste Jouffray, Carl Folke, and Johan Rockström. 2017. "Emergence of a Global Science: Business Initiative forOcean Stewardship.” Proceedings of the National Academy of Sciences of the United States of America 114 (34): 9038-43.

Pramod, Ganapathiraju, Katrina Nakamura, Tony J. Pitcher, and Leslie Delagran. 2014. "Estimates of Illegal and Unreported Fish in Seafood Imports to the USA." Marine Policy 48 (September): 102-13.

Posner, Richard A. 1993. "Richard Rorty's Politics.” Critical Review 7 (1): 33-39.

Quirk, Joel. 2006."The Anti-Slavery Project: Linking the Historical and Contemporary.” Human Rights Quarterly 28 (3): 565-98.

Ramasastry, Anita. 2002. "Corporate Complicity: From Nuremberg to Rangoon-An 
Examination of Forced Labor Cases and Their Impact on the Liability of Multinational Corporations." Berkeley Journal of International Law 20 (1): 91-159.

Ramberg, Bjørn. 2008. "Rorty, Davidson, and the Future of Metaphysics in America." In The Oxford Handbook of American Philosophy, edited by Cheryl Misak, 430-48.

New York: Oxford University Press.

Ramberg, Bjørn. 2009. "Richard Rorty." In The Stanford Encyclopedia of Philosophy, edited by E. N. Zalta. https://plato.stanford.edu/archives/spr2009/entries/rorty/.

Ramberg, Bjørn. 2013. "Being Constructive: On Misak’s Creation of Pragmatism.” Transactions of the Charles S. Peirce Society 49 (3): 396-404.

Rorty, Richard. 1961. "Recent Metaphilosophy.” Review of Metaphysics 15 (2): 299-318.

Rorty, Richard. 1979. Philosophy and the Mirror of Nature. Princeton, NJ: Princeton University Press.

Rorty, Richard. 1982. Consequences of Pragmatism. Minneapolis: University of Minnesota Press.

Rorty, Richard. 1989. Contingency, Irony, and Solidarity. Cambridge: Cambridge University Press.

Rorty, Richard. 1991a. "Feminism and Pragmatism." Tanner Lectures on Human V alues. Delivered at the University of Michigan, December 7.

Rorty, Richard. 1991b. Objectivity, Relativism, and Truth. Philosophical Papers 1. Cambridge: Cambridge University Press.

Rorty, Richard. 1997a. “Justice as a Larger Loyalty." Ethical Perspectives 4 (3): 139-51.

Rorty, Richard. 1997b. Truth, Politics and "Post-modernism." 1997 Spinoza Lectures. Amsterdam: Van Gorcum.

Rorty, Richard. 1998a. Achieving Our Country: Leftist Thought in Twentieth-Century America. 
Cambridge, MA: Harvard University Press.

Rorty, Richard. 1998b. "Can American Egalitarianism Survive a Globalized Economy?” Ruffin Series of the Society for Business Ethics 1: 1-6.

Rorty, Richard. 1998c. Truth and Progress. Philosophical Papers 3. Cambridge: Cambridge University Press.

Rorty, Richard. 1999a. "Human Rights, Rationality and Sentimentality.” In The Politics of Human Rights, edited by Obrad Savic, 67-82. London: Verso.

Rorty, Richard. 1999b. Philosophy and Social Hope. London: Penguin Books.

Rorty, Richard. 2000. "Response to Jürgen Habermas.” In Rorty and His Critics, edited by R. B. Brandom, 56-64. Malden, MA: Blackwell.

Rorty, Richard. 2006a. "Is Philosophy Relevant to Applied Ethics?” Business Ethics Quarterly 16 (3): 369-80.

Rorty, Richard. 2006b. "Pragmatism as Anti-authoritarianism." Revue Internationale de Philosophie 1999 53 (1): 7-20. Reprinted in A Companion to Pragmatism, edited by J. R. Shook and J. Margolis, 257-66. Malden, MA: Blackwell.

Rorty, Richard. 2006c. "Replies to Koehn, De George, and Werhane.” Business Ethics Quarterly 16 (3): 409-413.

Rorty, Richard. 2007a. "Dewey and Posner on Pragmatism and Moral Progress." University of Chicago Law Review 74 (3): 915-27.

Rorty, Richard. 2007b. Philosophy as Cultural Politics. Philosophical Papers 4. New York: Cambridge University Press.

Rozin, Paul, Laura Lowery, Sumio Imada, and Jonathan Haidt. 1999. "The CAD Triad Hypothesis: A Mapping between Three Moral Emotions (Contempt, Anger, Disgust) and Three Moral Codes (Community, Autonomy, and Divinity)." Journal of Personality 
and Social Psychology 76 (4): 574-86.

Sabadoz, Cameron, and Abraham Singer. 2017. “Talk Ain't Cheap: Political CSR and the Challenges of Corporate Deliberation.” Business Ethics Quarterly 27 (2): $183-211$.

Schwab, Klaus. 2016. The Fourth Industrial Revolution. Geneva: World Economic Forum.

Skinner, E. Benjamin. 2012. "Slaves Put Squid on U.S. Dining Tables from South Pacific Catch.” Bloomberg Business Week, February 23. https://www.bloomberg. $\mathrm{com} /$ news/articles/2012-02-23/slaves-put-squid-on-u-s-dining-tables-from-southpacificcatch.

Stout, Jeffrey. 1988. Ethics after Babel: The Languages of Morals and Their Discontents. Boston: Beacon Press.

Strauss, Kendra. 2012. “Coerced, Forced and Unfree Labour: Geographies of Exploitation in Contemporary Labour Markets.” Geography Compass 6 (3): 137-48.

Stringer, Christina, D. Hugh Whittaker, and Glenn Simmons. 2016. “New Zealand's Turbulent Waters: The Use of Forced Labour in the Fishing Industry.” Global Networks: A Journal of Transnational Affairs 16 (1): 3-24.

Tickler, David, Jessica J. Meeuwig, Katharine Bryant, Fiona David, John A. H. Forrest, Elise Gordon, Jacqueline Joudo Larsen et al. 2018. "Modern Slavery and the Race to Fish." Nature Communications 9 (1): 1-9.

Voparil, Christopher J. 2011. "Rortyan Cultural Politics and the Problem of Speaking for Others." Contemporary Pragmatism 8 (1): 115-31.

Voparil, Christopher J. 2014. “Taking Other Human Beings Seriously: Rorty's Ethics of Choice and Responsibility." Contemporary Pragmatism 11 (1): 83-102.

Voparil, Christopher J., and Richard J. Bernstein, eds. 2010. The Rorty Reader. West Sussex: 
Wiley-Blackwell.

Werhane, Patricia H. 1999. Moral Imagination and Management Decision Making. Oxford: Oxford University Press.

Werhane, Patricia H. 2006. "A Place for Philosophers in Applied Ethics and the Role of Moral Reasoning in Moral Imagination: A Response to Richard Rorty.” Business Ethics Quarterly 16 (3): 401-408.

Wettstein, Florian. 2009. Multinational Corporations and Global Justice: Human Rights Obligations of a Quasi-governmental Institution. Stanford, CA: Stanford Business Books.

Whelan, Glen. 2012. “The Political Perspective of Corporate Social Responsibility: A Critical Research Agenda.” Business Ethics Quarterly 22 (4): 709-37.

Wicks, Andrew C. 1990. "Norman Bowie and Richard Rorty on Multinationals: Does Business Ethics Need 'Metaphysical Comfort?”' Journal of Business Ethics 9 (3): $191-200$.

Wicks, Andrew C. 1993. "Divide and Conquer? Rorty's Distinction between the Public and the Private." Soundings 76 (4): 551-69.

Wicks, Andrew C., and R. Edward Freeman. 1998. "Organization Studies and the New Pragmatism: Positivism, Anti-positivism, and the Search for Ethics.” Organization Science 9 (2): 123-40.

Young, Iris Marion. 2000. Inclusion and Democracy. New York: Oxford University Press. 